\title{
Impact of Perkinsus sp. on Manila clam Ruditapes philippinarum beds
}

\author{
J. Cigarría ${ }^{1, *}$, C. Rodríguez ${ }^{2}$ J. M. Fernández ${ }^{3}$ \\ 'Area de Zoología, Departamento Biología de Organismos y Sistemas, Universidad de Oviedo, E-33071 Oviedo, Asturies, Spain \\ ${ }^{2}$ Centro de Experimentación Pesquera, Consejería de Medio Rural y Pesca, E-33760 Castropol, Asturies, Spain \\ ${ }^{3}$ CULTIMAR S.A., Paseo del Muelle s/n, E-33760 Castropol, Asturies, Spain
}

\begin{abstract}
Three million Manila clams (Ruditapes philippinarum, Adams \& Reeve 1850) were sown in 3 sets: $A, B$ and $P(0.65,0.66$ and $0.79 \mathrm{~g}$ per clam respectively) in intertidal beds of the Eo estuary (Asturies, N Spain). In January 1994 Perkinsus sp. was detected in set P. Growth, survival and prevalence of Perkinsus sp. were periodically examined during a 2 yr period. Clam growth and survival were unaffected by the parasites in all sets, probably due to the low prevalence of Perkinsus $\mathrm{sp}$. (which ranged from 2 to $9 \%$ ). This low prevalence, in turn, may have been due to the fact that water temperature remained below $20^{\circ} \mathrm{C}$. We suggest that, in most cases, clam mortality associated with Perkinsus $\mathrm{sp}$. may be minimized with adequate management of clam beds. The disease could be controlled if stressful growing conditions such as high densities, harvesting, or overcrowding in depuration plants are avoided during the warmer months. Additionally, we recommend 2 prophylactic measures: the removal of sets with parasitized clams and the introduction of unparasitized seed in clam culture areas.
\end{abstract}

KEY WORDS: Perkinsus sp. Ruditapes philippinarum Manila clam - Management Eo estuary

\section{INTRODUCTION}

Parasitic protozoa of the genus Perkinsus (Apicomplexa, Perkinsea) are common in molluscs. Perkins (1993) reported Perkinsus spp. in 63 species of bivalves which ranged from temperate to tropical waters. Perkinsus spp. have historically been associated with high mortalities in cultured species, including Crassostrea virginica in the USA (Andrews \& Hewatt 1957), Tridacna gigas in Australia (Goggin \& Lester 1987). and Ruditapes decussatus in Portugal (Ruano \& Cachola 1986) and Italy (Da Ros \& Canzonier 1985). In Spain the disease was first detected in $R$. decussatus in 1985 (González et al. 1987), and later in both $R$. philippinarum and $R$. decussatus (Villalba \& Navas 1988 , Figueras et al. 1992).

Since the introduction of the Manila clam Ruditapes philippinarum in France (1972), England and Spain (1980) and in Italy (1982) (Breber 1985, Flassch \& Leborgne 1992), its culture has been widely developed

•E-mail: cigarria@sci.cpd.uniovi.es in European waters. At present, Perkinsus sp. is not included in the legislation of the European Union as a 'pathogen of obligatory declaration' (93/54/EU), and therefore transplantations of Manila clams throughout European countries have resulted in the introduction of Perkinsus sp. to most clam culture areas.

The presence of Perkinsus sp. could endanger both cultured clams and clams harvested in natural beds. However, the effects of parasites on clam populations are not well known. In this study, the relationship of Perkinsus sp. to growth and survival of Manila clam beds was examined over a 2 yr period.

\section{MATERIALS AND METHODS}

In June 1993, 3 sets, A, B and P, of 1 million clams each, of Manila clam spat $(0.65,0.66$ and $0.79 \mathrm{~g}$ per clam respectively) from 3 different hatcheries were planted in intertidal beds of CULTIMAR S.A. in the Eo estuary (N Spain) (Fig. 1). The sets were planted in sand-gravel beds and covered with plastic netting ( $6 \mathrm{~mm}$ mesh size) at densities of approximately 260 clams $\mathrm{m}^{-2}$. 


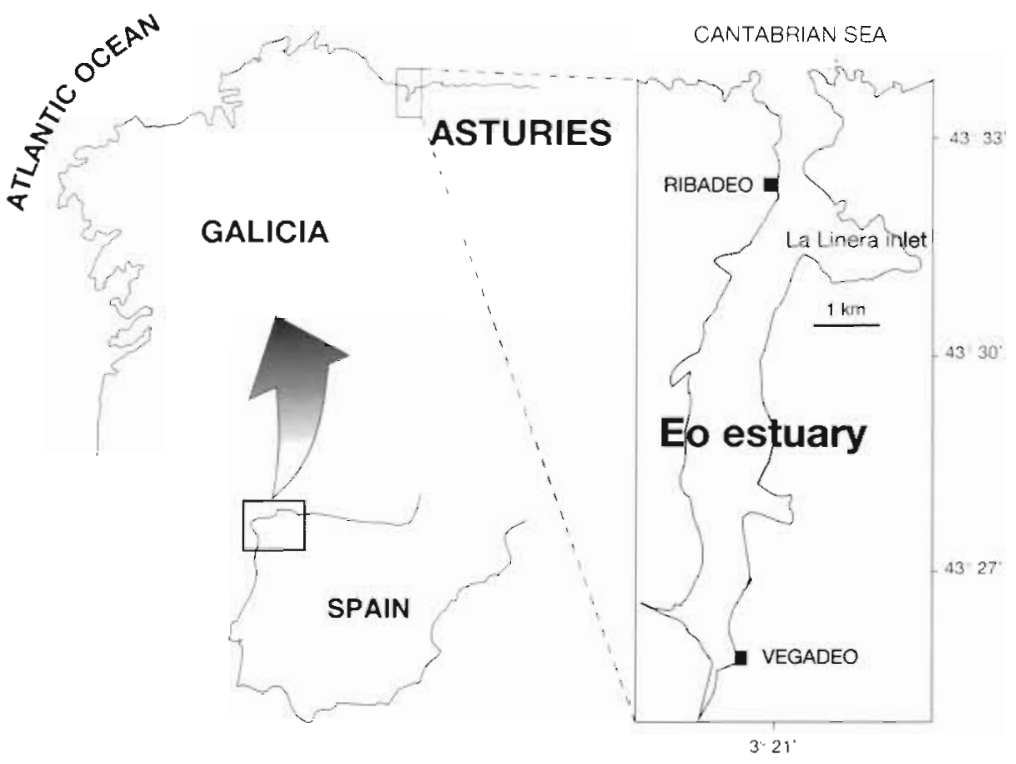

Fig. 1. Eo estuary. Culture took place in La Linera inlet

We collected bi- or trimonthly samples from June 1993 to August 1995 in order to record growth and survival. The sampling method was as follows: a plastic square frame $\left(0.25 \mathrm{~m}^{2}\right)$ was placed into the sandbed; a sand cut was taken out in a screen; it was sieved in seawater through a mesh of $4 \mathrm{~mm}$ and the number of live clams was counted. The procedure was repeated 15 times for each set to increase the precision of estimating mean survival ( $S$ ) (IFREMER 1988). A sample of 100 individuals was randomly selected from each set. Each clam was weighed $(W)$ to the nearest $0.01 \mathrm{~g}$ using a digital balance.

In January 1994, samples from 11 different Manila clam sets cultured in the Eo estuary were collected from each set and gill tissue (2 demibranchs per clam) was used following the thioglycollate procedure of Ray (1966) to detect the presence of the Perkinsus sp. It was detected in only 1 set (set P) from the 11 sets analyzed. To study the evolution of the parasitized set and to compare it with the unparasitized sets, 100 clams were collected trimonthly from set $P$ and the closest $(<60 \mathrm{~m})$ sets $A$ and $B$

Temperature $\left({ }^{\circ} \mathrm{C}\right)$ and salinity $(\%)$ values were recorded daily, at the high tide level and $1 \mathrm{~m}$ depth, near the clam. beds (Fig. 2)

We used 1-way analysis of variance to study final survival data (in percentage). Previously we tested normality (Lilliefors' test, $p>0.1$ ) and homogeneity of variances (Bartlett's test, $\mathrm{p}>0.05$ ).

\section{RESULTS}

Initial and final weights, survival of Manila clams and prevalence of Perkinsus sp. in sets $A, B$ and $P$ are shown in Table 1 The growth rates of unparasitized clams in sets $A$ and $B$ were similar to the growth rates of clams in set $P$, which were infected with the parasite (Fig 3). Similarly, no significant differences $(p>0.2)$ were found in clam survival among sets (Fig. 4) at the end of the culture (summer 1995), indicating that there were no effects due to the parasite at the prevalences observed. As a prophylactic measure, a large number of parasitized clams (set P) were harvested in October-November 1994, and during this period a moderate mortality increase (14\%) was observed (Fig. 4). All sets were harvested totally during summer 1995.

Water temperature in the Eo estuary (Fig. 2) varied from $12^{\circ} \mathrm{C}$ in December 1992 to $20^{\circ} \mathrm{C}$ in September 1994 , always below the $25^{\circ} \mathrm{C}$ optimum for Perkinsus sp. (Vigario \& Ruano 1992).

\section{DISCUSSION}

During the 27 mo of our experiment, both growth and survival of Manila clams showed similar patterns in sets $A, B$ and $P$. As usual, commercial clams (13 to $16 \mathrm{~g}$ per clam) were harvested after $2 \mathrm{yr}$ of culture (Fig. 3), which indicates that clam growth was not affected by Perkinsus sp. at the prevalences observed during this study (never greater than 9\%) (Fig. 4). Moreover, survival was similar in the 3 sets and only a moderate increase in mortality was observed following partial harvesting in set P (October-November 1994).

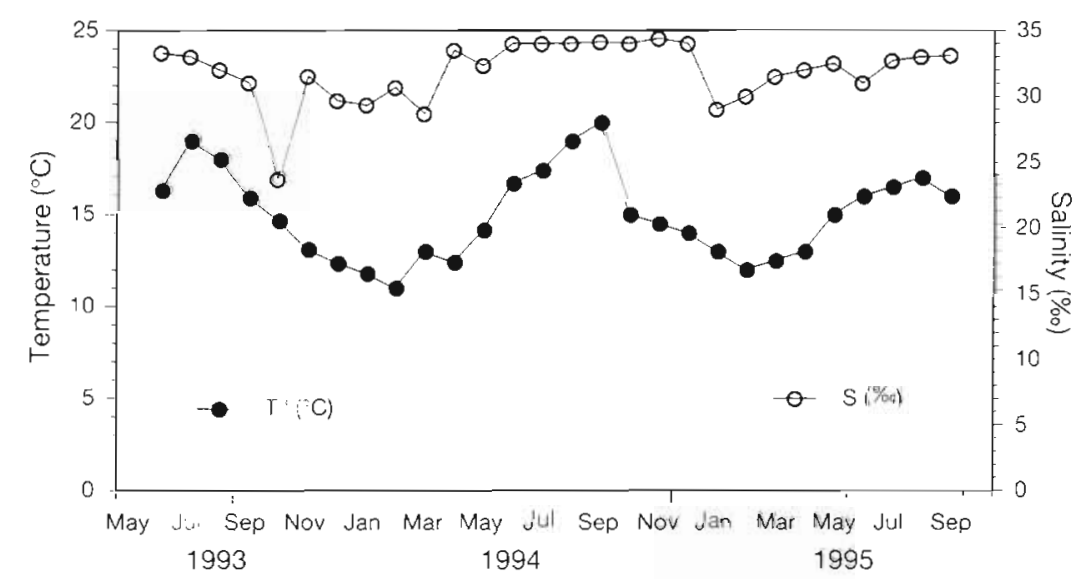

Fig. 2. Temperature $\left({ }^{\circ} \mathrm{C}\right)$ and salınity $(\%)$ of Eo estuary 
Table 1. Survival (S), weight ( $W$ ) and prevalence of Perkinsus sp. $(P)$ in Manila clam sets. Numbers represent the mean value $( \pm 1$ SD) in percentage (survival, prevalence) and grams (weight) during the period June 1993-August 1995

\begin{tabular}{|lllcccc|}
\hline Set & $S_{\text {initual }}$ & \multicolumn{1}{c}{$S_{\text {Iinal }}$} & $W_{\text {initial }}$ & $W_{\text {tinal }}$ & $P_{\text {initial }}$ & $P_{\text {timal }}$ \\
\hline A & 100 & $53.8(8.4)$ & $0.65(0.11)$ & $14.1(3.06)$ & 0 & 0 \\
B & 100 & $56.3(12.6)$ & $0.66(0.25)$ & $13.3(2.51)$ & 0 & 0 \\
P & 100 & $53.4(9.4)$ & $0.79(0.19)$ & $15.5(2.33)$ & $?$ & 7 \\
\hline
\end{tabular}

Possibly, this mortality was due to harvesting, a phenomenon which has frequently been observed by the shellfish industry.

Since the parasite was not observed in clams from set $A$ or $B$, prevailing conditions of temperature, salinity and density (always below $2 \mathrm{~kg} \mathrm{~m}^{-2}$ ) during this experiment may have prevented successful transmission of the parasite to the closest clams in set $\mathrm{A}$ or $\mathrm{B}$ in the Eo

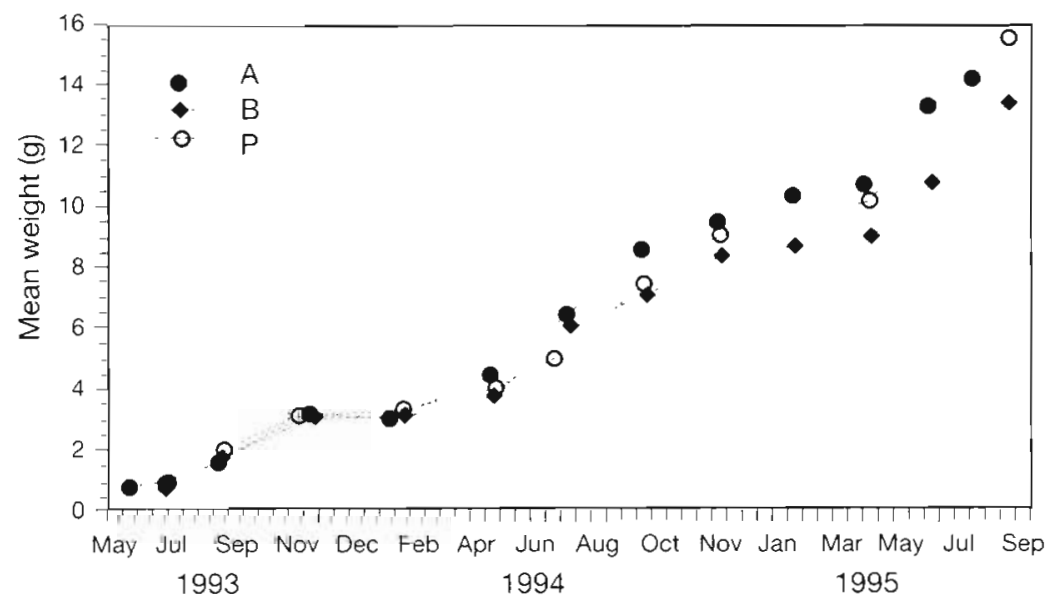

Fig. 3. Ruditapes philippinarum. Mean live weight of the 3 sets (A, B and P) of Manila clam

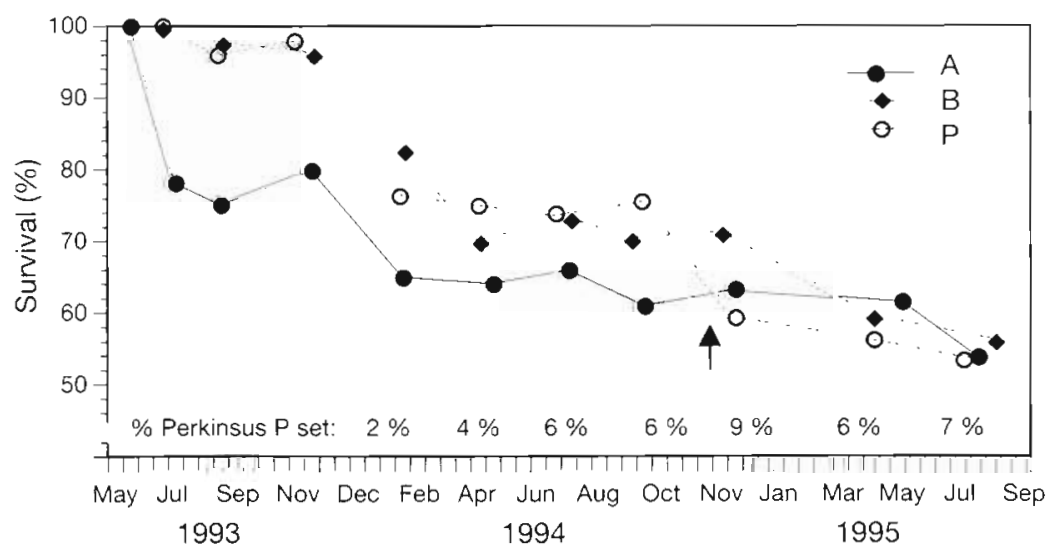

Fig. 4. Ruditapes philippinarum. Mean survival of the 3 sets (A, B and P) of Manila clam and percentage of parasitized clams in set $P$. Arrow indicates date of partial harvesting estuary. Furthermore, Perkinsus sp. was not found in the natural populations of Ruditapes decussatus in the Eo estuary (C. Rodriguez unpubl. data). Apparently the source of Perkinsus sp. infections in the clams in set $P$ was the hatchery stock from which they were derived, since other clams from the hatchery were found to be parasitized by the parasite as well (September 1994).

In contrast to other reports, Perkinsus sp. prevalence and clam mortality in our study showed no significant increases during high summer temperatures despite the fact that Perkinsus sp. is more active then. Vigario \& Ruano (1992) demostrated that infection and development of Perkinsus sp. in Ruditapes decussatus are favoured by water temperatures near $25^{\circ} \mathrm{C}$, and temperatures below $15^{\circ} \mathrm{C}$ prevent parasite reproduction. Santmartí et al. (1995) reported variable mortalities (10 to $90 \%$ ) of Manila clams during summer 1990 in the Ebro Delta (Spain) associated with high prevalences of Perkinsus sp. (83 to $100 \%$ ).

Clam mortality attributed to Perkinsus $\mathrm{sp}$. is usually associated with stress due to environmental factors (e.g. high temperature, since $25^{\circ} \mathrm{C}$ is the upper thermal threshold of Ruditapes philippinarum; Bernard 1983) and/or inadequate culture management (e.g. high clam densities). Although the lethality of Perkinsus sp. is clear (Villalba et al. 1993), disease develops only under optimal conditions. For example, F. Ruano (pers. comm.) in Portugal observed high prevalences of Perkinsus sp. in $R$. decussatus and high mortalities in dense beds $\left(8 \mathrm{~kg} \mathrm{~m}^{-2}\right)$ when temperatures reached $25^{\circ} \mathrm{C}$. Stress due to high temperatures and crowding facilitated the development of disease. Furthermore, high losses of clams were attributed to Perkinsus sp. in a Spanish clam depuration plant, while no mortalities were detected in natural beds with low parasite prevalences (Figueras et al. 1992). This difference in mortality may be explained by the lower prevalence of the parasite in natural beds and the lack of stressors such as the process of harvesting or/and holding in the plant. Similarly, McLaughlin \& Farley (1995) suggested that Mya arenaria mortality due to Perkinsus sp. may occur when clams are heavily infected and/or stressed by other diseases and environmental factors. 
Since temperature appears to be the main environmental factor in mortalities associated with Perkinsus sp., management techniques may be developed for 2 types of culture zones, according to temperature. Firstly, in areas where summer temperatures are below $20^{\circ} \mathrm{C}$, the disease could be controlled if stressful growing conditions such as high densities, harvesting, and overcrowding in depuration plants are avoided. Secondly, in areas where maximum temperatures are near $25^{\circ} \mathrm{C}$, the best technique, besides the abovementioned precautions, would be to harvest all of the clam population before the temperature reaches $25^{\circ} \mathrm{C}$ and very heavy Perkinsus sp. pressure registered. In both zones we recommended 2 prophylactic measures: the total harvesting of sets with parasited clams and the introduction of unparasitized seed in the culture areas.

Acknowledgements. The authors thank Dr F. Ruano and especially Shawn McLaughlin for suggestions which helped to improve the manuscript.

\section{LITERATURE CITED}

Andrews JD, Hewatt WG (1957) Oyster mortality in Virginia II. The fungus disease caused by Dermocystidium marinum in oysters of Chesapeake Bay. Ecol. Monogr $27: 1-25$

Bernard FR (1983) Physiology and the mariculture of some Northeastern Pacific bivalve molluscs. Can Spec Publ Fish Aquat Sci 63:1-24

Breber P (1985) L'introduzione e l'allevamento in Italia dell'arsella del Pacifico, Tapes semidecussatus Reeve (Bivalvia; Veneridae). Oebalia XI-2 N S:675-680

Da Ros L, Canzonier WJ (1985) Perkinsus, a protistan threat to bivalve culture in the Mediterranean basin. Bull Eur Assoc Fish Pathol 5(2):23-25

Figueras A, Robledo JAF, Novoa B (1992) Occurrence of haplosporidian and Perkinsus-like infections in carpetshell clams, Ruditapes decussatus (Linnaeus, 1758), of the Ría de Vigo (Galicia, NW Spain). J Shellfish Res 11: $377-382$

Responsible Subject Editor: A. K. Sparks, Seattle, Washington, USA
Flassch JP, Leborgne Y (1992). Introduction in Europe, from 1972 to 1980, of the Japanese Manıla clam (Tapes philippinarum) and the effects on aquaculture production and natural settlement. ICES Mar Sci Symp 194:92-96

Goggin CL, Lester RJG (1987) Occurrence of Perkinsus species (Protozoa, Apicomplexa) in bivalves from the Great Barrier Reef. Dis Aquat Org 3:113-117

González Herrero V, Peñas Rodriguez J, Diaz Martinez A (1987) Dermocystidiosis en almeja fina portuguesa de importación. Cuad Marisq Publ Tec 12:695-700

IFREMER (1988) La palourde, dossier d'élevage. IFREMER, Paris

McLaughlin SM, Farley CA (1995) Prevalence of Perkinsus sp. in Chesapeake Bay softshell clams (Mya arenaria). J Shellfish Res 14, 1:245

Perkins FO (1993) Infection diseases of molluscs. In: Couch JA, Fournie JW (eds) Pathobiology of marine and estuarine organisms. Advances in fisheries science. CRC Press Inc., Boca Raton, p 255-287

Ray SM (1966) A review of the method for detecting Dermocysttidium marinum with suggested modifications and precautions. Proc Natl Shellfish Assoc 54:55-69

Ruano F, Cachola R (1986) Outbreak of a severe epizootic of Perkinsus marinus (Levin-78) at Ria de Faro clam's culture beds. In: Proc 2nd Int Colloq Pathol Mar Aquac (PAMAQ II). Oporto, Portugal, p 41-42

Santmartí MM, García VJ, Montes J, Pech A, Durfort M (1995) Seguimiento del protozoo Perkinsus sp., en las poblaciones de Tapes decussatus y Tapes semidecussatus del Delta del Ebro. In: Castelló F, Calderer A (eds) Actas del V Congreso Nacional de Acuicultura, 10-13 May 1995, S. Carlos de la Rápita, Spain. Universidad de Barcelona, p 260-265

Vigário AM, Ruano F (1992) Influencia de diferentes factores ambientais no desenvolvimento in vitro do agente patogénico Perkinsus atlanticus (Apicomplexa: Perkinsea). Seminário de Aquacultura Mediterrânica 91. INIP, Publicaçoes Avulsas 19, Lisbon, p 407-412

Villalba A, Lopez MC, Carballal MJ (1993) Parásitos y alteraciones patológicas de tres especies de almeja Ruditapes decussatus, Venerupis pullastra y Venerupis rhomboides en las rías gallegas. In: Cervino, Landin, Coo, Guerra, Torre (eds) Actas del IV Congreso Nacional de Acuicultura, 21-24 September 1993, Vilanova de Arousa, p 551-556

Villalba A, Navas Jl (1988) Occurrence of Minchinia tapetis and a Perkinsus-like parasite in cultured clams, Ruditapes decussatus and $R$. philippinarum, from South Atlantic coast of Spain. Preliminary results. Proc 3rd Int Colloq Patho] Mar Aquac (PAMAQ III). Gloucester Point, Virginia, USA, p 5?-58

Manuscript first received: April 8, 1996

Revised version accepted: January 28, 1997 